\title{
ОСОБЛИВОСТІ ГЕНДЕРНО МАРКОВАНИХ ФРАЗЕОЛОГІЗМІВ ІЗ МАСКУЛІННИМИ АНТРОПОМЕТРИЧНИМИ КОМПОНЕНТАМИ В НІМЕЦЬКІЙ МОВІ
}

У статті розглянуто особливості гендерно маркованих фразеологізмів із маскулінним антропометричним компонентом. Мета роботи - розкриття специфічних рис гендерно маркованих фразеологізмів, у компонентному складі яких міститься антропометричний компонент на позначення чоловіка. Мета зумовлює виконання завдань, що націлені на дослідження основних напрямів гендерних досліджень у фразеології й аналіз особливостей маскулінних антропометризмів із загальним значенням «особа чоловічої статі» в компонентному складі гендерно маркованих фразеологізмів. Завдяки методу компонентного аналізу виокремлено фразеологічні одиниці 3 такими антропометричними компонентами: Kerl, Bube, Junge, Bursche, Knabe, Herr, Typ. Аналіз словникових дефініцій дав підставу визначити семантичне значення фразеологізмів із цими компонентами, а застосування методів кореляції мовних і позамовних явищ та лінгвокультурного аналізу сприяло виявленню взаємозалежності соціальної сфери носіїв мови із семантикою досліджуваних мовних елементів та їх здатністю відображати культурно зумовлені погляди німецького народу на чоловічу стать. Установлено, що компонент Bube називає зазвичай осіб чоловічої статі, але може вказувати й на жінку або взагалі втрачати семантичну гендерну ознаку. Компонент Kerl указує лише на особу чоловічої статі. Фразеологізми з Junge у своєму складі є синомінічними до фразеологічних одиниць із компонентом Kerl та характеризують чоловічу стать, можуть позначати професію чи рід занять або навіть семантизувати нетрадиційну сексуальну орієнтацію. Фразеологізми з компонентом Кпаbе характеризують чоловіка 3 огляду на вік, але можуть слугувати звертанням до нього. Антропометричний компонент Herr має найбільший фразеотворчий потенціал, передає здатність тримати ситуацію під контролем, семантизує владу чи ії відсутність, а також професію або рід занять. Окрім того, ФО з компонентом Herr вживаються для оцінки особи чоловічої статі. За умови негативної характеристики Herr набуває іронічного змісту з огляду на первинну семантику цього компонента (пан, повелитель). Фразеологізми з Тур позначають особу чоловічої статі або особу загалом.

Ключові слова: фразеологія, гендер, гендерно маркований фразеологізм, антропометричний компонент, маскулінність.

Вступ. У лінгвістичних дослідженнях останніх років чільне місце займає використання антропоцентричного принципу, зріс науковий інтерес щодо мовних одиниць, котрі слугують для позначення людини. А оскільки людина являє собою дві статі - чоловічу та жіночу, - то виникає необхідність урахування серед усіх іiі антропоморфних параметрів, які відображаються в мові, також і гендерних ознак [6]. Що ж стосується фразеологізмів, то їхньою загальною рисою є те, що вони володіють антропометричною природою, оскільки характеристика об'єкта дійсності, котрий позначається фразеологічними одиницями, завжди співвідноситься 3 властивостями людини. Тому «більшість фразеологізмів зосереджена на характеристиці особи, на подіях, пов'язаних із національним виявленням цих властивостей у поведінці, у ментальності, почуттях, соціальному стані тощо» [13, с. 122], що, власне, і зумовлює актуальність дослідження антропометричних компонентів у складі гендерно маркованих фразеологізмів.

Кожна лінгвокультура володіє своїм набором антропометричних лексем, за допомогою яких здійснюється позначення осіб різних статей, хоча, певна річ, існує низка одиниць, які тією чи іншою мірою притаманні всім мовам: передусім, це власне поняття «чоловік» / «жінка». Ці одиниці можна охарактеризувати як базові. Вони називають осіб та $\epsilon$ в кожній мові, бо відображають традиційний суспільний устрій. Мета цієї наукової розвідки - розкриття специфічних рис гендерно маркованих фразеологізмів із маскулінним антропометричним компонентом у німецькій мові. Це передбачає виконання таких завдань: розглянути основні напрями гендерних досліджень у фразеології, проаналізувати особливості маскулінних антропометризмів із загальним значенням «особа чоловічої статі» у компонентному складі гендерно маркованих фразеологізмів.

Основна частина робіт стосується дослідження гендеру у фразеології, аналізують відображення гендерних стереотипів у фразеологічних одиницях (ФО) на матеріалі різних мов: української - І. Гапєєва [4], Н. Тернова [15]; англійської - Г. Висоцька [17], Н. Павленко [11],

(С) Лозииька М., 2020 
порівняльна характеристика 3 опорою на декілька мов - О. Пономарьова [12]. Мова та культура $\epsilon$ двома ідентифікаційними характеристиками етносу. А фразеологізми виступають як знаки культурної ідентичності, що характерні для всіх мов. Фразеологічний склад мови - це той пласт лексики, у якому лінгвокультурна спільнота визначає свою національну самобутність. У будьякій мові вони мають свої особливі форми вираження. Саме фразеологізми найвиразніше розкривають характер етнічної спільноти, відображують культурну ідентичність його представників. ФО як «знаки мови», культури виражають та утворюють культурну самосвідомість етносів, формують фразеологічну картину світу [14]. 3 огляду на це зростає інтерес науковців до лінгвокультурної специфіки гендерно маркованих фразеологізмів [3; 7; 18], оскільки саме у фразеологізмах, що містять у компонентному складі (структурний принцип) чи дефініції (семантичний принцип) компоненти на позначення статі, виявляється мовна репрезентація культурного виміру «маскулінність/фемінінність» [18]. Виокремлюючи групи фразеологізмів з гендерно маркованим планом вираження, спираючись на головний статево забарвлений компонент, І. Зикова [19] виділяє фразеологізми із антропометризмами, оскільки найменування осіб мають яскраве гендерне маркування, що дає змогу співвіднести їх із чоловіком чи жінкою. Фактично, антропометричні компоненти є експлікаторами маскулінності в гендерно маркованих фразеологізмах [1]. Вони слугують елементами, що визначають національну своєрідність фразеології.

Методи та методики дослідження. У процесі аналізу досліджуваних явищ ми послуговувалися комплексним підходом, який сприяє розв'язанню поставлених завдань. Комплексний підхід характеризується ефективністю, бо поєднує різні методи.

До опису гендерно маркованих фразеологізмів 3 маскулінним антропометричним компонентом залучено, передусім, принцип антропоцентризму, згідно з яким, головним фактором, що регламентує розвиток і функціонування фразеологічного фонду мови, є людський фактор. Людина (у нашому випадку чоловік) стає точкою відліку в аналізі гендерно маркованих фразеологізмів з антропометричним компонентом.

Методологічні положення й принципи знаходять своє тактичне втілення в методах дослідження. Будь-який метод лінгвістичного дослідження зумовлений метою, завданнями й аналізованим матеріалом лінгвістичного пошуку. У зв'язку з цим, у цій науковій розвідці ми застосовували первинні методи дослідження, що використовуються задля збору інформації, вивчення джерел тощо, та вторинні, які стають у пригоді під час обробки й аналізу отриманих даних. До первинних методів дослідження належать метод збору $і$ обробки інформаиії, що особливо актуальний під час опрацювання теоретичних джерел; метод лінгвістичного опису й спостереження, суть якого полягає в інвентаризації та систематизації, класифікації та інтерпретації фактів i явищ. Процес інвентаризації за допомогою описового методу здійснювався шляхом суцільної вибірки з лексикографічних джерел. Джерельною базою дослідження слугували фразеологічні онлайн-словники «Lexikon für Redewendungen», «OnlineLexikon zur diachronen Phraseologie» та «Німецько-український фразеологічний словник» за редакцією В. Гаврися й О. Пророченка. Загалом проаналізовано 73 фразеологічні одиниці, що відповідали критеріям відбору. Критерієм для виокремлення фразеологізмів слугували гендерні структурні маркери, для визначення яких ми послуговувалися структурними методами. Метод компонентного аналізу застосовано задля виокремлення саме тих фразеологізмів, що мають у своєму складі маскулінний антропометричний компонент.

Завдяки аналізу словникових дефініцій, що дає змогу визначити семну структуру мовних одиниць, нам удалося визначити семантичне значення фразеологізмів із маскулінними антропометричними компонентами. Метод кореляиії мовних $і$ позамовних явищ застосовано задля виявлення взаємозалежності соціальної сфери носіїв мови із семантичною структурою досліджуваних мовних елементів. Під час обробки й аналізу відібраних фразеологізмів застосовано лінгвокультурний аналіз, що розкриває здатність фразеологізмів із маскулінними антропометризмами відображати культурнообумовлені уявлення німецького народу про чоловіка та його роль у суспільстві. 
Результати та дискусії. Німецька лінгвокультура володіє унікальними засобами номінації осіб обох статей, які $\epsilon$ складовими компонентами гендерно маркованих фразеологізмів, що слугують не лише для ідентифікації осіб, але й для їх характеристики. Антропометричні лексеми із загальним значенням «Mann / Frau» постійно змінювалися, залежно від процесів, що відбувалися в суспільстві. Однак, як стверджує Д. Нюблінг, ці зміни не однаковою мірою відбувалися в цих лексемах. Так, у середньоверхньонімецькій мові аналогічно утворені композити «јunc-herre» - junger Herr, Edelknabe та «junc-vrouwe» - junge Herrin, Edelfräulein мали однакове значення, указуючи на чоловіка та жінку відповідно. Із часом ці дві лексеми стали мати діаметрально протилежні значення: Junker позначає сьогодні представника вищого класу, а Jungfer означає сексуально недосвідчену жінку та вживається зневажливо [9]. Така біологізація жінки імплікує, що вона, по-перше, відмовилася від виконання своєї біологічної функції, по-друге, через свій вік уже й не цікава протилежній статі. Учена, зазначає, що в обох випадках жінка оцінюється 3 погляду чоловіка. Назви ж чоловіків не біологізуються, оскільки чоловік, на відміну від жінки, мислиться у взаємозв'язку із світом, суспільством чи богами. Референтом щодо жінки виступають діти, сім'я та чоловік. Асиметричний розвиток названих вище композит підтверджує цю позицію [9].

До антропометризмів, що традиційно слугують на позначення осіб чоловічої статі та стали компонентами гендерно маркованих фразеологізмів, відносимо такі одиниці: Kerl, Bube, Junge, Bursche, Knabe, Herr, Typ.

Bube - хлопчик, слуга (середньоверхньонімецьке buobe). У фразеологізмах цей компонент указує на осіб чоловічої статі: nasser Bube - дурнуватий, недосвідчений юнак [10]. Компонент nass натякає на те, що в нього ще «молоко на губах не висохло». Чимало ФО з цим компонентом стосуються карточних ігор, оскільки Вube може означати гральну карту - валета: einen bösen Buben verhaften - побити валета більшою картою [10]; die bösen Buben locken підсунути гравщеві в гранд великі карти, щоб спонукати його бити валетом [10]. Окрім того, деякі ФО вказують одночасно на обидві статі: der böse Bube sein - особа, щзо у всьому винна [8].

Компонент Kerl означає «чоловік, хлопець», а ФО з цим компонентом називають особу чоловічої статі: ein hergelaufener Kerl - зайда, чужинеиь [5, с. 377]. Уживаються в розмовній мові та характеризують вдачу чоловіка: ein ausgepichter Kerl-npoйдucвim [5, c. 377]; Das ist ein Kerl! - Оие хлопець! Хоч куди козак! [5, с. 377]; ein fixer Kerl-молодець, хлопець хоч куди [5, c. 377]; ein geriebener (gerissener, durchtriebener) Kerl-nройдисвіт, бита голова, бувалий хлопеиь [5, с. 377]; ein ganzer Kerl - вправний / сміливий / у повній бойовій готовності чоловік [8]; ein Kerl wie ein Stück Strumpf - незграбний, ні на щз непридатний чоловік [10]; verfluchter Kerl1) аморальний чоловік; 2) досвідчений, але безсовісний чоловік; 3) відчайдушний, мужній чоловік; 4) Задирака [10]; klarer Kerl - хороший, вправний чоловік [10]; ein Kerl wie ein Pfund (ein Viertel) Wurst - неенергійний чоловік [10]. Деякі фразеологізми описують чоловічу зовнішність: schnatzer Kerl-молодий чоловік, щз гарно виглядає [10].

ФО можуть стосуватися до військової сфери та вказувати на військовослужбовця: alter $K e r l$ - солдат, щзо давно на службі [10]. 3 огляду на наведені приклади, стає очевидним, що крізь призму цього компонента маємо лише характеристику чоловіка, яка може бути як позитивною, так і негативною.

Оскільки ЛО Junge вказує на чоловіків, то й ФО з цим компонентом характеризують чоловічу стать: ein schwerer Junge - карний злочинець [5, с. 363]; ein strammer Junge - здоровий, міиний хлопець [8]; gesunder Junge - прагматик [10]; fauler Junge - ненадійний чоловік, зрадник [10]; diesjähriger Junge - дурна недосвідчена людина [10]; dufter Junge - 1) кмітлива особа чоловічої статі; 2) хитрий злодій; 3) чоловік-повія, якому можна довіряти [10]; heißer Junge niдозрюваний [10]. Такі ФО можуть називати професію чи рід занять: grüner Junge - 1) учень лісника; 2) полічейський; 3) недосвідчений зухвалий молодик [10]; feuchter Junge - pекрут, новобранець, молодий солдат [10]. У словнику знаходимо ФО, що називає чоловіка нетрадиційної сексуальної орієнтації: süßer Junge - гомосексуаліст [10]. Цікаво, що фразеологізм Із цим компонентом може називати особу жіночої статі, котра поводиться як 
хлопчисько, зокрема маленьку дівчинку: ein halber Junge sein - nустувати, поводитися як хлопчисько (вживається стосовно маленьких дівчаток) [10].

Аналіз словникової дефініції ФО ein fixer Junge у різних словниках дав підставу виокремити два аспекти значення: «молодець» [5, с. 363]; «досвідчений чоловік, ділок 3 переважно обманними намірами» [10].

Фразеологізми з компонентом Bursche утворюють синоніми до ФО з компонентом Junge: schwerer Bursche - тяжский злочинеиь, неодноразово засуджений [10]; ein sauberer (netter) Bursche - нічого собі молодчик! [5, с. 132]; ein starker Bursche (ein Baum von einem Burschen) здоровенний парубійко [5, с. 132]; alter Bursche - друзяка [5, с. 131]; trockener Bursche - 1) чоловік з вродженою кмітливістю; 2) Флегматик [10]. ФО з цим компонентом можуть означати не особу, а предмет чи елементи озброєння: dicker Bursche - важка бойова броньована машина [10]; hartnäckiger Bursche - зуб, який може бути видалений оперативно [10]. Можуть імплікувати рід діяльності: bemooster Bursche - cmyдент cmаршого курсу [10], а також нейтралізувати гендерний аспект у семантиці: Bursche von der anderen Feldpostnummer - воєнний супротивний [10].

ФО $з$ компонентом Knabe семантизують чоловіка з огляду на його вік: betagter Knabe стариий чоловік [10]; ein reifer Кпаbе - старий подружній чоловік [10]; ein halbwüchsiger Knabe - підліток [5, с. 388]; nasser Knabe - 1) недосвідчений молодий чоловік, який вдає із себе дорослого 2) пияк [10]. До вікової характеристики чоловіка може додаватися оцінка чи риса, якою він вирізняється: kesser Knabe - старий чуттєвий чоловік [10]; ein komischer Knabe - дивак [5, с. 388]; besonders weiser Knabe - всезнайка [10]; bedienter Knabe - хороший, кмітливий, надійний одноліток підлітка [10]; типterer Knabe - шибеник [10]. ФО з компонентом Кпаbе може слугувати звертанням до особи чоловічої статі: ein alter Knabe - cmapuй, старина [5, с. 388] та навіть називати особу жіночої статі: weiblicher Knabe - дівчина в чоловічому вбранні [10].

Herr - чоловік, пан, уживається під час звертання до особи чоловічої статі. Herr походить від her, що мало значення «високий» та позначало особу, вищу за рангом, яка має владу наказувати, повелівати. Слово також співвідносилося 3 божественною владою (Herrgott). Перенесення значення лише на чоловічу стать $є$ наслідком німецьких патріархальних традицій. У широкому сенсі поняття почало згодом застосуватися стосовно до господаря в домі. У нинішньлму значенні у якості ввічливого звертання до чоловіка слово почало застосовуватися лише 3 XVII ст. Здатність тримати ситуацію під контролем, володіти нею передається за допомогою ФО з компонентом Herr, дає підставу зробити висновок про те, що чоловік трактується як володар: einer Sache Herr werden - отримати контроль над чимось, подолати труднощі [8]; der Herr seiner Gefühle sein - тримати почуття під контролем [8]; der Herr im Haus / Hause sein - бути господарем в домі, здійснювати владу [5, с. 325].

Подібні ФО, але із заперечною часткою вказують на втрату влади та впливу особи: nicht mehr der Herr im eigenen Haus sein - бути позбавленим влади [5, с. 42]; nicht mehr Herr seiner selbst sein - діяти нерозсудливо [8]; nicht mehr Herr seiner Sinne sein - бути розгубленим [5, c. 325]; nicht mehr Herr seines Kopfes sein - несповна розуму [5, с. 325].

Компонент Herr слугує для утворення ФО, що вказують на професію чи рід занять, що виконує чоловік: die Herren von Ar und Halm - хлібороби [5, с. 44]; Herr Justiz - нібито ввічливе звертання до праиівника суду [10]; Herr in Schwarz - третейський суддя [10]. В останньому прикладі чорний колір указує на традиційне вбрання третейського судді. Важлива роль батька як особи, яка стоїть на чолі родини утілюється у ФО mein alter Herr - батько [10]. Чоловіка, котрий все забороняє своїй дружині, влучно семантизує ФО Herr und Verbieter [10]. Цей фразеологізм $є$ модифікацією застарілого звертання до одруженого чоловіка - mein Herr und Gebieter [8]. Окрім того, ФО з компонентом Herr можуть вживатися для оцінки особи чоловічої статі. При цьому, якщо ця характеристика є негативною, Herr набуває іронічного змісту з огляду на первинну семантику цього компонента (пан, повелитель): fester Herr - майбутній наречений [10]; später Herr - старий холостяк [10]; Herr von und zи - фантазер, особа, щчо гне кирпу [10]; möblierter Herr - мешканець умебльованої кімнати [10]; Herr von Habenichts - збіднілий чоловік 3 благородними манерами [10]; Herr Arschloch persönlich - неприємний чоловік [10]. 
Як бачимо, компонент Herr, що є типовим звертанням до чоловіка, утілює у ФО чоловічу владу, домінування, а із заперечним елементом - відсутність чи втрату цього домінування над ситуацією та самим собою; може називати чоловіків за родом їхньої діяльності чи характеризувати їх загалом.

Компонент Тур семантизує молодого чоловіка, що вирізняється певними рисами. Слово належить до розмовної мови та володіє великим потенціалом у творенні ФО. Такі фразеологізми позначають особу чоловічої статі або особу загалом: ein mieser Typ / eine miese Type несимпатична / безхарактерна / підла людина [8]; ein kaputter Typ / eine kaputte Type sein асоиіальний, душевно хворий [8]; eine schräge Type / ein schräger Typ sein - капризна / підозріла людина [8]; drollige Tyре - веселун [10]; billige Tyре - дешевий тип, дешева людина [10]. ФО такого плану може виражати ставлення до особи: јemandes Typ sein-nодобатися кому-небудь [8].

Висновки. Отже, гендерно марковані фразеологізми 3 «чоловічими» антропонімами вказують переважно на чоловіка за такими основними критеріями, як характеристика особи, ситуація чи процес, професія або рід занять, влада та домінування чи їх відсутність, звертання до особи чоловічої статі. Відзначимо, що саме компонент Herr є найбільш продуктивним у процесі творення фразеологічних одиниць. Неочікувано, що чоловічі антропометризми лише двічі вказують на жінку та один раз - на всі статі, на відміну від компонента Mann, що може співвідноситись із людиною загалом. Усі інші антропоніми, хоч і імплікують загальне значення «чоловік», мають однозначну гендерну векторність, що вказує лише на особу чоловічої статі. Перспективним убачаємо дослідження фемінінних антропометризмів, що $\epsilon$ компонентами гендерно маркованих фразеологічних одиниць.

\section{References}

1. Bylytsya, Ulyana. 2015. "Henderna relevantnist komparatyvnykh frazeolohichnykh nominatsiy lyudyny v anhlomovniy kartyni svitu". Prykarpatskyi visnyk NTSh. Slovo 2(30): 158-167.

2. Dikunova, O. A., ed. 2017. Linhvokulturolohiya yak intehrovana haluz movoznavstva: naukovo-dopomizhnyy bibliohrafichnyy pokazhchyk. Kryvyi Rih: Biblioteka Kryvorizkoho derzhavnoho pedahohichnoho universytetu.

3. Fedina, Olena. 2020. "Frazeosemantychne pole kontseptu lyudyna v rosiys'kiy movi: funktsionalnoprahmatychnyy aspekt". PhD abstract, Dnipro.

4. Hapyeyeva, Iryna. 2019. "Genderni komponenty ta zasoby stereotypizatsiyi v ukrayinskiy frazeolohiyi". Aktualni pytannya humanitarnykh nauk 24 (1): 61-65.

5. Havrys, Vasyl and Prorochenko Oleksandr, ed. 1981. Nimetsko-ukrayinskyi frazeolohichnyi slovnyk. Kyiv: Radyanska shkola.

6. Kirilina, A. 2003. "Vozmozhnosti gendernogo pokhoda $\mathrm{v}$ antropooriyentirovannom izuchenii yazyka i kommunikatsii". Accessed December 8, 2020. URL: http://www/gender-ryazan.ru/school/.

7. Lebedenko, Yu. M. 2017. "Linhvokulturolohichni osoblyvosti henderno markovanykh FO". STUDIA SLOBOZHANICA. Visnyk vystavkovo-muzeynoho tsentru 3. (Materialy mizhnarodnoyi naukovo-metodychnoyi konferentsiyi „Slobozhanskyi humanitariy - 2017“ 3 bereznya 2017 r.). Kharkiv: FOP Tarasenko, 235-242.

8. Lexikon für Redewendungen. Accessed December 8, 2020. URL: https://www.redensarten-index.de/suche.php.

9. Nübling, Damaris. 2015. Von der ,Jungfrau 'zur, Magd', vom ,Mädchen 'zur ,Prostituierten ':Die Pejorisierung der Frauenbezeichnungen als Zerrspiegel der Kultur und als Effekt männlicher Galanterie? Accessed December 8, 2020. URL: https://www.germanistik.uni-mainz.de/files/2015/03/Nubling-2011-Pejorisierung-Frauenbezeichnungen.pdf (дата звернення: 24.06.2020).

10. Online-Lexikon zur diachronen Phraseologie. Accessed December 8, 2020. URL: https://www.oldphras.net/web/ ( дата звернення: 24.06.2020).

11. Pavlenko, Nataliya. 2016. "Gender v strukture i semantike angliyskikh frazeologizmov-nominatsiy cheloveka po kharakteru mezhlichnostnykh otnosheniy". Applied Linguistics: Scientific Journal. U.K.: Oxford University Press Issue2(5), Vol. 37: 1297-1303.

12. Ponomarova, O. I. 2018. "Gendernyy aspekt funktsionuvannya naymenuvan osib za rodom zanyat u frazeolohiyi ukrayinskoyi, anhliyskoyi ta nimetskoyi mov". Naukovyy chasopys NPU im. N. P. Drahomanova. Seriya 9. Suchasni tendentsiyi rozvytku mov, Vyp. 16: 184-194.

13. Rozhon, Valentyna. "Frazeolohichni zasoby nominatsiyi lyudyny u skhidnopodilskykh hovirkakh". Movoznavchyy visnyk. Zbirnyk naukovykh prats 12-13: 122-125. Accessed December 8, 2020. URL: http://surl.li/dpxs.

14. Sadovey, Mikhaela and Byalyk Vasyl. 2019. "Frazeolohichna kartynu svitu vs. movna kartyna svitu v suchasniy linhvistytsi". Naukovi zapysky Tsentralnoukrayinskoho derzhavnoho pedahohichnoho universytetu imeni Volodymyra Vynnychenka. Seriya: Filolohichni nauky. Vyp. 175: 112-115. 
15. Ternova, Nataliya. 2014. "Reprezentatsiya hendernykh stereotypiv u "Frazeolohichnomu slovnyku skhidnoslobozhanskykh i stepovykh hovirok Donbasu". Linhvistychni doslidzhennya: zb. naukovykh prats KhNPU im. H. S. Skovorody, Vyp. 38: 59-64.

16. Tikan, Ya. H. and Yarmak D. O. 2017. "Frazeolohichni zasoby vyrazhennya kulturnoyi identychnosti predstavnykiv anhliyskoyi ta ukrayinskoyi linhvokultur”. Visnyk NTUU „KPI“. Filolohiya. Pedahohika 10: 50-53.

17. Vysotska, Nataliya. 2017. "Frazeolohichni zasoby realizatsiyi hendernykh stereotypiv". Universitetskaya nauka 3: $154-155$

18. Zakharova, Ulyana. 2014. "Yazykovaya reprezentatsiya gendernykh smyslov kulturnogo izmereniya „maskulinnost' / femininnost'“ v russkoy i angliyskoy frazeologii”. Sovremennyye problemy nauki $i$ obrazovaniya 5: 499-503.

19. Zykova, Irina. 2003. Sposoby konstruirovaniya gendera v angliyskoy frazeologii. M.: Editorial URSS.

Лозицкая Мария. Особенности гендерно маркированных фразеологизмов с маскулинными антропометрическими компонентами в немецком языке. В статье изучаются особенности гендерно маркированных фразеологизмов с маскулинным антропометрическим компонентом. Цель исследования - раскрытие специфических черт гендерно маркированных фразеологизмов, в компонентном составе которых содержится антропометрический компонент для обозначения мужчины. Цель предопределяет решение задач, которые состоят в исследовании основных направлений гендерных исследований в фразеологии и анализе особенностей маскулинных антропометризмов с общим значением «лицо мужского пола» в компонентном составе гендерно маркированных фразеологизмов. Благодаря методу компонентного анализа были выделены фразеологические единицы с такими антропометризмами: Kerl, Bube, Junge, Bursche, Knabe, Herr, Typ. Анализ словарных дефиниций позволил определить семантическое значение фразеологизмов с этими антропометрическими компонентами, а применение методов корреляции языковых и внеязыковых явлений и лингвокультурного анализа способствовало выявлению взаимозависимости социальной среды носителей языка с семантикой исследуемых языковых элементов и их способностью отображать культурно обусловленные взгляды немецкого народа на мужской пол. Определяется, что компонент Bube называет обычно лиц мужского пола, но может указывать и на женщину или вообще терять гендерное маркирование в семантике. Компонент $\mathrm{Kerl}$ называет и характеризует исключительно лиц мужского пола. Фразеологизмы с Junge в своем составе являются синонимичными к фразеологическим единицам с компонентом Kerl и обозначают мужской пол, могут указывать на профессию, род занятий или даже семантизируют нетрадиционную сексуальную ориентацию. Фразеологизмы с компонентом Knabe используются для возрастной характеристики мужчины, но могут служить и обращением к нему. Антропометрический компонент Herr имеет наибольший потенциал, касающийся создания фразеологических единиц, передает способность держать ситуацию под контролем, семантизирует власть или ее отсутствие, а также профессию или род занятий. Кроме того, фразеологизмы с компонентом Herr используются для оценки лица мужского пола. При отрицательной характеристике Herr приобретает иронический оттенок значения, учитывая первичную семантику этого компонента (господин, повелитель). Фразеологизмы с Тур обозначают лицо мужского пола или человека в целом.

Ключевые слова: фразеология, гендер, гендерно маркированный фразеологизм, антропометрический компонент, маскулинность.

Lozytska Mariia. Features of Gender Marked Phraseological Units with Masculine Anthropometric Components in German. The article deals with the peculiarities of gender marked phraseological units with a masculine anthropometric component. The aim of the study is to reveal the specific features of gender marked phraseological units, the composition of which contains an anthropometric component that denote a man. The goal determines the solution of problems aimed at studying the main directions of gender researches in phraseology and analysis of the features of masculine anthropometric components with the general meaning «male person» in the composition of gender marked phraseology. Using the method of component analysis, phraseological units with the following anthropometric components were singled out: Kerl, Bube, Junge, Bursche, Knabe, Herr, Typ. Analysis of vocabulary definitions allowed to determine the semantic meaning of phraseological units with these anthropometric components, and the use of methods of correlation of linguistic and extralinguistic phenomena and linguacultural analysis helped to identify the interdependence of the social sphere of native speakers with the semantics of the studied linguistic elements. It has been established that the component Bube usually refers to males, but may also indicate a woman or lose gender features in its semantic. The component Kerl names and characterizes exclusively the male person. Phraseological units with Junge are synonymic to phraseological units with Kerl, characterize the male sex, may indicate a profession or occupation, or even semantize a non-traditional sexual orientation. Phraseological units with Knabe characterize a man in view of his age, but can serve as an appeal to him. The anthropometric component Herr has the greatest phrase-forming potential, conveys the ability to keep the situation under control, semantizes power or its absence, as well as profession or occupation. In addition, phraseological units with Herr are used to assess male identity. Given the negative characteristics of Herr acquires an ironic meaning given the primary semantics of this component (lord). Phraseological units with Typ denote a male person or a person in general.

Key words: phraseology, gender, gender marked phraseological unit, anthropometric component, masculinity. 